\title{
SUPERCAPACITOR PROPERTIES UNDER CHANGING LOAD
}

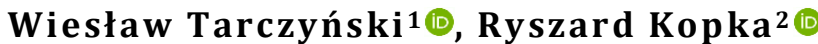

Opole University of Technology, Faculty of Electrical Engineering, Automatic Control and Informatics, Prószkowska 76 Str., 45-758 Opole, Poland; e-mail: w.tarczynski@po.edu.pl, r.kopka@po.edu.pl; ORCID ID: 10000-0002-3039-0295, 20000-0002-7074-3008

\begin{abstract}
This paper presents the results of analyses of the series resonance phenomenon in a system containing supercapacitors. The specific features of such components, especially the diffusion processes, cause their dynamic properties significantly differ from those of typical capacitors. In contrast to other authors work, the presented results were obtained during discharging of supercapacitors through periodically changing resistor. Such procedure corresponds to conditions when supercapacitors can be discharged by periodically changing loads. Analysis of resonance phenomena is a very important task; especially in power supply circuits, where supercapacitors often act as energy storage elements. The tests carried out for selected supercapacitors and frequencies range were verified practically using a specially prepared test system.
\end{abstract}

Keywords:

electrical resonance, supercapacitor, variable load.

Research article

(C) 2019 Wiesław Tarczyński, Ryszard Kopka This is an open access article licensed under the Creative Commons Attribution-NonCommercial-NoDerivatives 4.0 license (http://creativecommons.org/licenses/by-nc-nd/4.0/) 


\section{INTRODUCTION}

Supercapacitors as components that accumulate very large amounts of energy and characterized by very high charging and discharging currents, currently find a very wide range of applications. One such area is power supply. In combination with periodic changes in the discharge current, the presence of reactance components $(L C)$ in supercapacitors may lead to dangerous consequences resulting from the phenomenon of resonance. Research on resonance phenomena in circuits with supercapacitors is conducted by many authors $[4,5,6,8,10]$. In simulation studies, supercapacitor models are often defined using fractional differential equations $[2,6$, $7,9]$. Nevertheless, in all works, the resonance effect in the supercapacitor's charging circuit is generated by a periodically changing power source. However, a different situation may occur under real-life conditions, where a charged supercapacitor becames a supply unit and the resonance effect may be caused by periodically changing loads. The specific properties of supercapacitor which result from diffusion mechanisms cause their dynamic properties to differ significantly from those of typical capacitors $[1,3,10]$. This is of particular importance in the process of designing electronic circuits, especially in such cases as selecting the operating frequency of impulse power supplies. Furthermore, in contrast to standard capacitors, in the case of supercapacitor elements modelled with fractional differential equations there are two different resonance frequencies which fulfil the amplitude and phase conditions $[10,11,12]$.

\section{SUPERCAPACITOR MODEL}

The general equivalent circuit of supercapacitor $C_{x}$ is presented in fig. 1 [13]. The equivalent circuit consists of ideal capacitor $C$, series resistance $r_{s}$, inductance $l_{s}$ and parallel resistance $r_{l}$. Capacitor $C$ represents the capacitance of a supercapacitor, resistance $r_{s}$ represents the active resistance of leads and internal connections, coil $l_{s}$ represents the inductance of leads and the inductance related to the structure (design) of the capacitor, and finally $r_{l}$ represents the losses associated with leakage current (imperfection of the dielectric).

An attempt was made to determine the values of individual components in the equivalent circuit of real supercapacitor $C_{x}$. First, simulation calculations of the behaviour of the capacitor in the measurement circuit were performed for the approximate values of the equivalent supercapacitor circuit, as shown in fig. 1. Voltage waveform $U_{c}$ was observed at different frequencies of source signal $E_{S}$. 


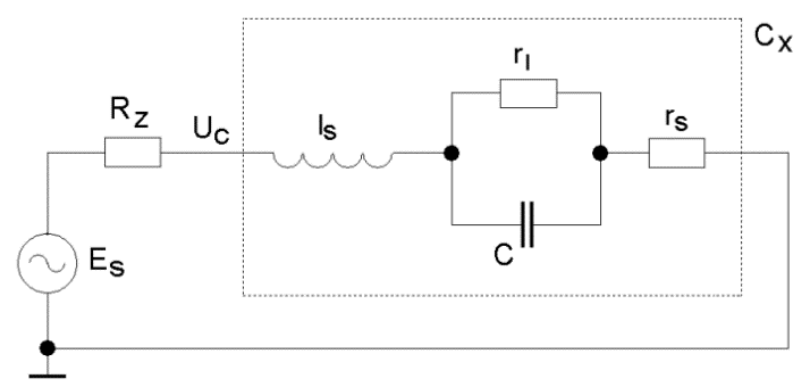

Fig. 1. Schematic diagram of the circuit adopted for simulation calculations

The simulation was performed for frequencies in the range from $100 \mu \mathrm{Hz}$ to $1 \mathrm{MHz}$. The conditions under which the simulation calculations were carried out and the results are shown in fig. 2 and 3. All simulations were performed using the PSpice software. The purpose of the waveforms shown in fig. 3 and 4 is to show only the impact of changes in selected parameters on the result. These values do not correspond to the actual values of specific elements, but only show the impact of their qualitative changes on the output signal.

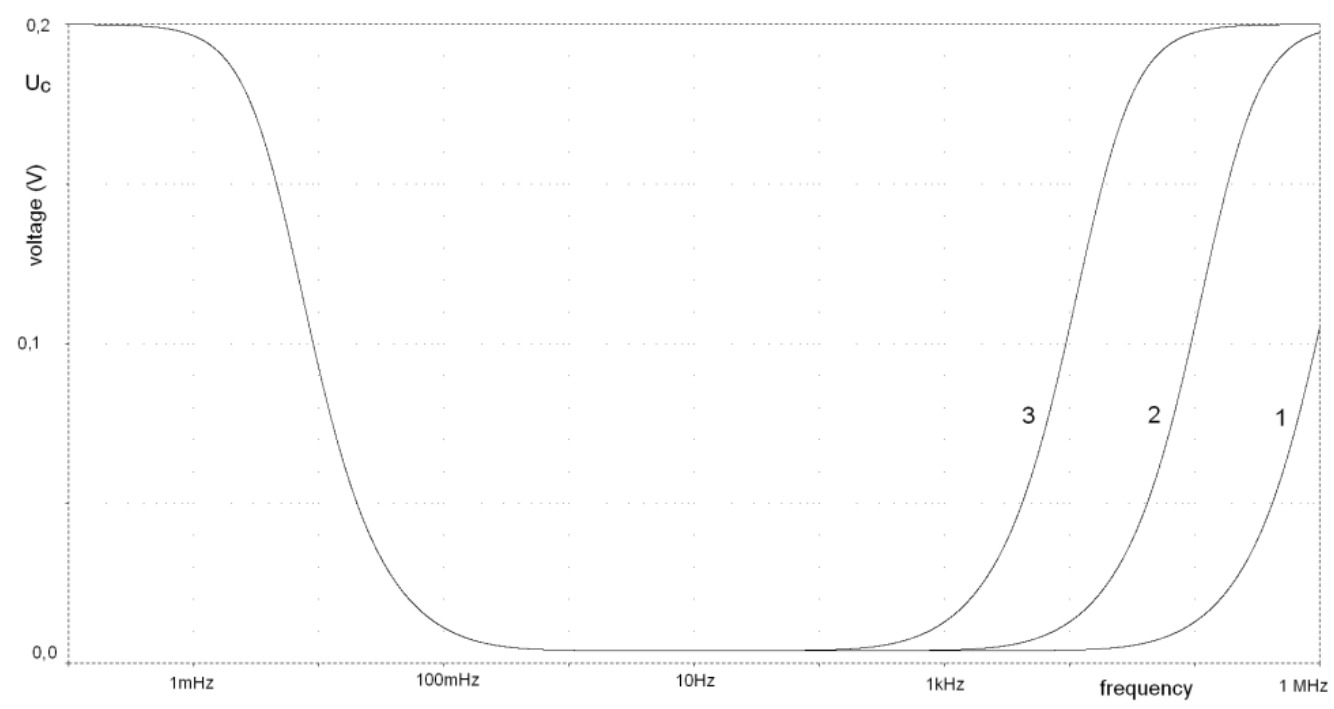

Fig. 2. The supercapacitor voltage $U_{c}$ vs. frequencies in the circuit shown in fig. 1 for: $C=3 \mathrm{~F}$ and for: $1-l_{s}=1 \mu \mathrm{H}, 2-l_{s}=10 \mu \mathrm{H}, 3-l_{s}=100 \mu \mathrm{H}$ 


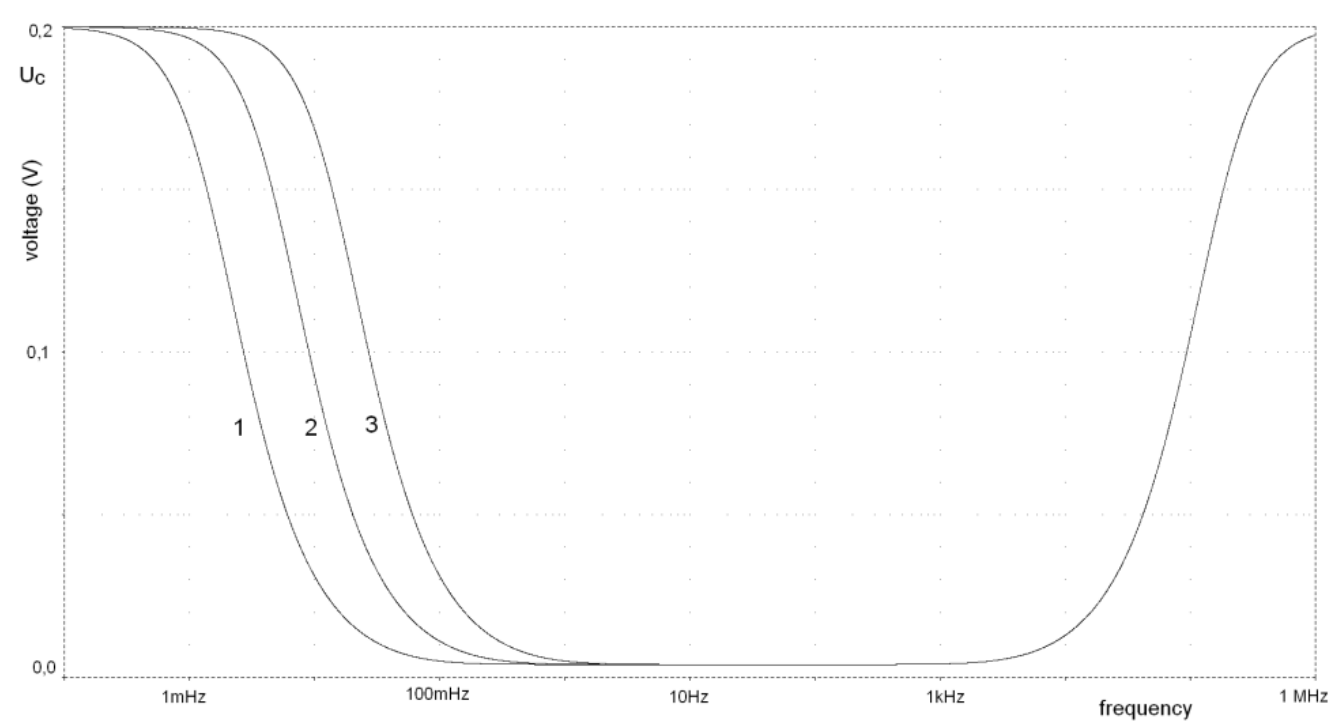

Fig. 3. The supercapacitor voltage $U_{c}$ vs. frequencies in the circuit shown in fig. 1 for: $l_{s}=10 \mu \mathrm{H}$ and for: $1-C=1 \mathrm{~F}, 2-C=3 \mathrm{~F}, 3-C=10 \mathrm{~F}$

Experimental determination of the values for equivalent circuit components as shown in fig. 1 is very difficult and time-consuming. Measurements with a frequency signal of $100 \mu \mathrm{Hz}$ imply that a measurement within one period must be taken over approx. 3 hours. In turn, in the case of high frequencies, i.e. above $10 \mathrm{kHz}$, it is difficult to distinguish the influence of the capacitor's inductance from the inductance of its leads and measuring system components. As can be seen in fig. 2 and 3, in the low frequency range the capacitance of the capacitor solely determines the properties of circuit $C$, and in the high frequency range (above $10 \mathrm{kHz}$ ) it is only its inductance that determines the properties of the circuit. Even though the schematic diagram includes coil $l_{s}$ and a capacitor $C$, the circuit between the outputs does not exhibit properties characteristic of resonance circuit $L C$. This can be explained by the very large capacitance of capacitor $C$ and the relatively small value of inductance $l_{s}$, which results in a series resonance circuit of a very low $Q$ factor [8]. The $Q$ factor for a resonance circuit with equivalent series resistance $r_{s}$ and coil $l_{s}$ is defined as

$$
Q=\frac{\omega_{0} l_{s}}{r_{s}}
$$

where

$\omega_{0}-$ resonance frequency. 


\section{STRUCTURE OF THE MEASURING SYSTEM AND SIMULATION RESULTS}

The behaviour of the supercapacitor during sinusoidal discharge at different frequencies was measured in the measuring system shown in fig. 4. The task of the system is to make it possible to observe the reaction of supercapacitor $C_{x}$, and more precisely of the voltage between the supercapacitor terminals, to a variable value of the discharge current. The model of tested capacitor $C_{x}$ has been replaced by serial connection of the ideal capacitor $C$ and equivalent series resistance $r_{s}$.

The operating amplifier $W$ and transistor $T$ work within a class A amplifier circuit, in which transistor drain $T$ is loaded by resistor $R_{r}$. Resistors $R_{1}$ and $R_{2}$ are used to determine the quiescent output voltage of the amplifier, i.e. when the amplitude of source signal $E_{S}$ is zero. The non-reversible input of amplifier $W$ is controlled in relation to the reference level by the sum of voltage on resistor $R_{1}$ and the transience source value of source $E_{s}$. The transient value of discharge current $I_{r}$ depends on the transient difference between voltage $U_{c}$ and the voltage at the output of voltage follower $U_{w}$. The value of discharge current $I_{r}$ of capacitor $C_{x}$ can be estimated from the dependency

$$
I_{r}=\frac{U_{c}(t)-U_{w}(t)}{R_{r}}
$$

while voltage $U_{w}$ is defined as

$$
U_{w}=\frac{U_{c}(t) R_{1}}{R_{1}+R_{2}}+U_{s}(t)
$$

where $U_{s}(t)=A_{s} \sin (2 \pi f t)$.

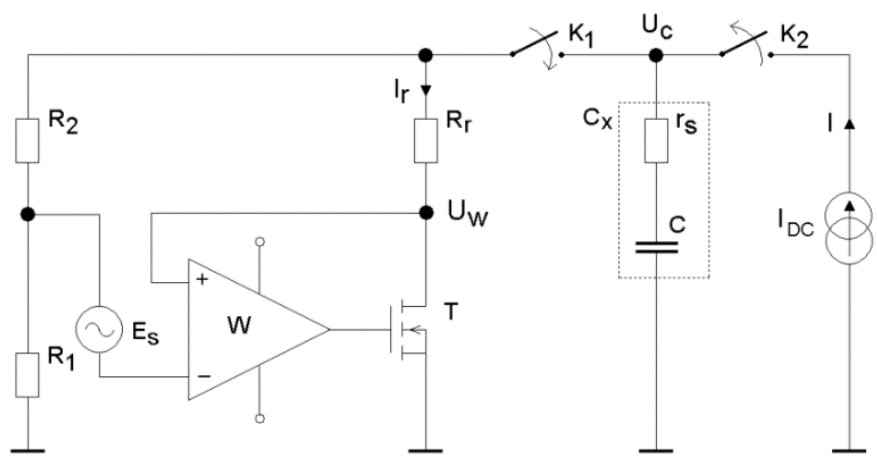

Fig. 4. Schematic diagram of the measuring system 
First, switch $K_{2}$ is shorted and supercapacitor $C_{x}$ is charged with current $I$ from current source $I_{D C}$ until voltage value $U_{c}$ reaches the maximum permissible value, i.e. $2.7 \mathrm{~V}$. Next, key $K_{2}$ is opened and key $K_{1}$ is shorted. The charged capacitor $C_{x}$ is then connected to the amplifier and supplies its output stage and resistor divider $R_{1}, R_{2}$. Capacitor $C_{x}$ is discharged by current $I_{r}$. The value of resistors $R_{1}$ and $R_{2}$ is high in relation to the value of resistor $R_{r}$ and therefore the discharge process in this circuit is determined solely by the value of resistor $R_{r}$ and the momentary value of voltages $U_{w}$ and $U_{c}$.

In the case of the measuring system shown in fig. 4, the calculation of the voltage waveform on capacitor $U_{c}$ and current $I_{r}$ in the circuit during the discharge of capacitor $C_{x}$ with sinusoidal current at different frequencies was performed. The results and calculation conditions are shown in fig. 5.

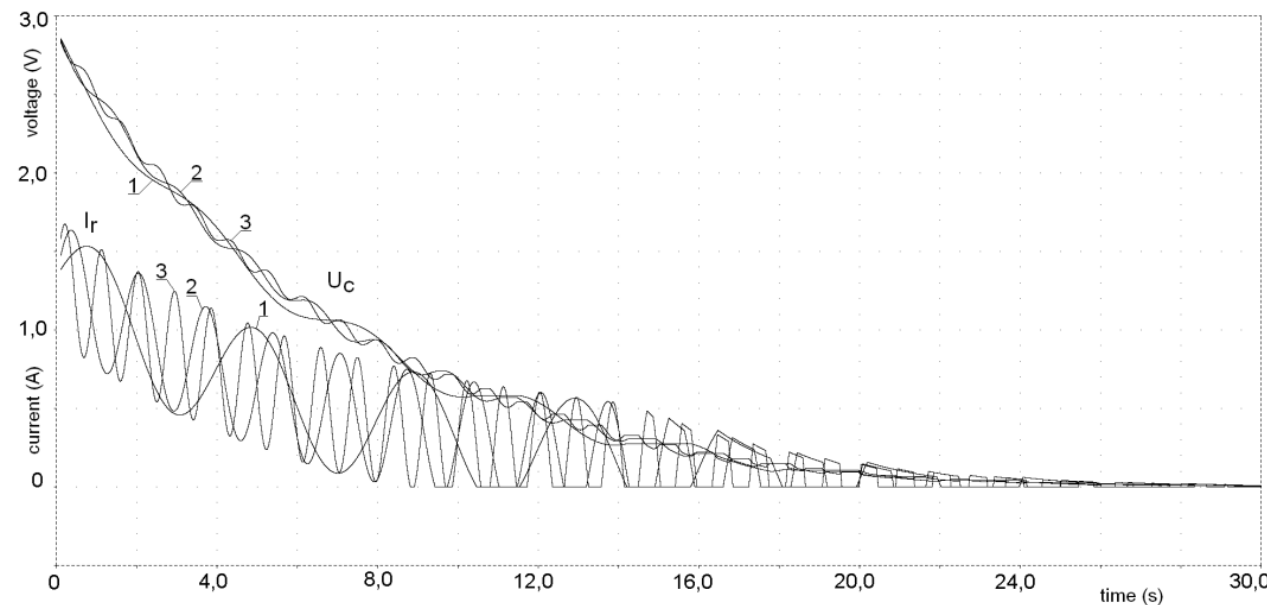

Fig. 5. Supercapacitor voltage $U_{c}$ and current $I_{r}$ if: $R_{1}=R_{2}=2 \mathrm{k} \Omega$, $r_{s}=0.1 \Omega, R_{r}=0.5 \Omega$, and for: $1-f=0.25 \mathrm{~Hz}, 2-f=0.6 \mathrm{~Hz}, 3-f=1.1 \mathrm{~Hz}$

Simulations were also made for a case in which resistor $R_{2}$ was replaced by DC voltage source $E_{p}$ with a voltage value equal to amplitude $A_{s}$ of source $E_{s}$. Such replaced causes that the supercapacitor discharge current changed within constant range regardless of the supercapacitor voltage $U_{c}$. The schematic diagram of the circuit is shown in fig. 6 , and the results of the simulations are shown in fig. 7.

Simulation calculations of the waveform of voltage $U_{c}$ and discharge current $I_{r}$ were also performed for the case where the voltage value of source $E_{p}$ equals zero. The results are presented in fig. 8. 


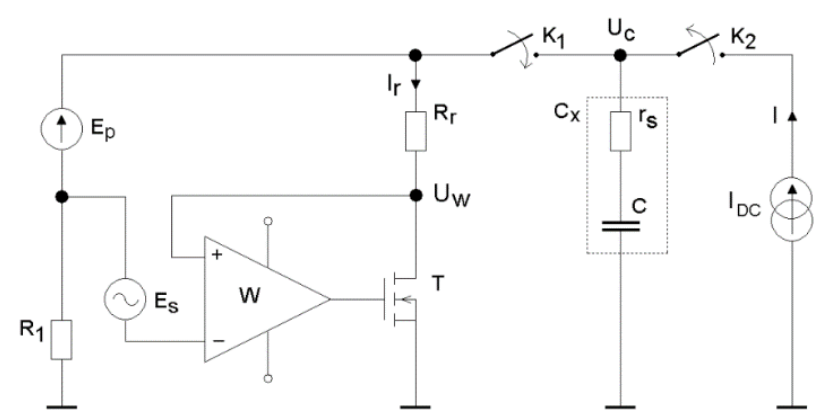

Fig. 6. Schematic diagram of a measuring system wherein resistor $R_{2}$ is replaced by source $E_{p}$

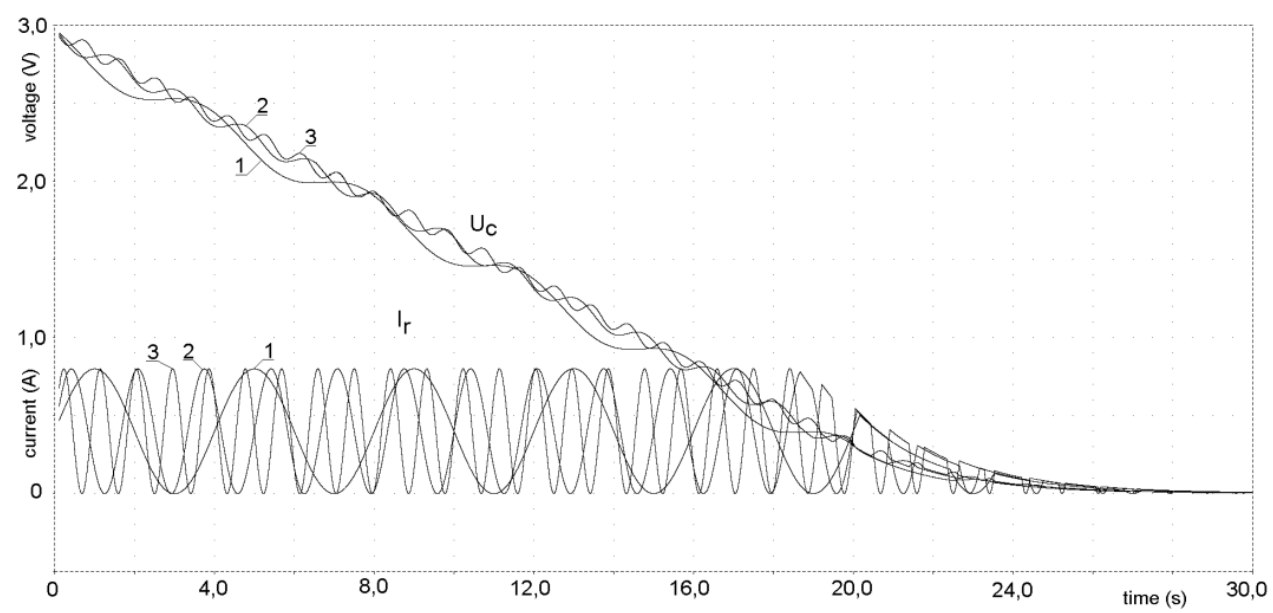

Fig. 7. Supercapacitor voltage $U_{c}$ and current $I_{r}$ when $R_{2}$ is replaced by source $E_{p}$ and $r_{s}=0.1 \Omega, R_{r}=0.5 \Omega$, and for: $1-f=0.25 \mathrm{~Hz}, 2-f=0.6 \mathrm{~Hz}, 3-f=1.1 \mathrm{~Hz}$

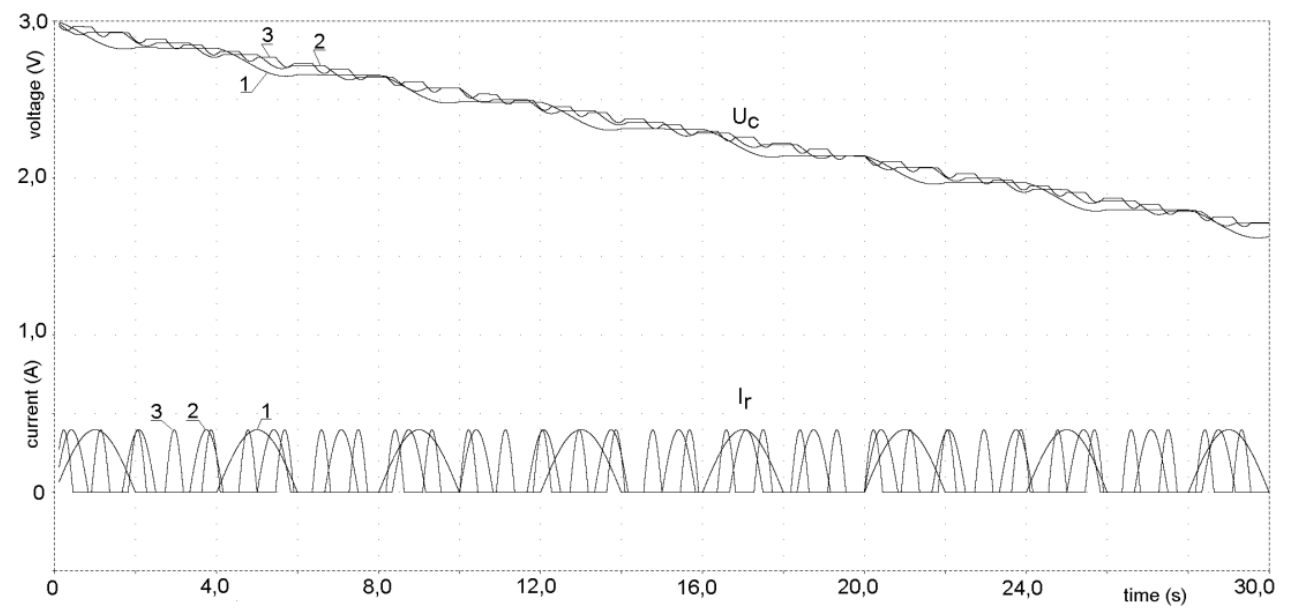

Fig. 8. Supercapacitor voltage $U_{c}$ and current $I_{r}$ if $E_{p}=0 \mathrm{~V}$, other data as shown in the fig. 7 
The measurements were carried out in the circuit shown in fig. 9, in which capacitor $C_{x}$, after being charged to maximum voltage $2.7 \mathrm{~V}$, is discharged by a resistor with a changing resistance value within the range from $R_{r}$ to $R_{r}+R_{z}$. This is to reflect the load on capacitor $C_{x}$ exerted by a receiver which changes the current draw within a certain value range.

A variable-resistance resistor was implemented using a unipolar MOSFET transistor. The operating point of the transistor was selected so as to locate it in a part of the static characteristics in which it operates as a voltage-controlled resistor (resistance area), which results in $r_{D S}=f\left(U_{G S}\right)$. A measurement circuit using a MOSFET transistor as a voltage-controlled resistor $R_{z}$ is presented in Fig. 10 . Voltage source $E_{z}$ determines the transistor's quiescent point in the resistance area and source $E_{S}$ determines the range of changes in this area. The value of the capacitor's discharge resistance will be defined as

$$
R_{r}+R_{z}(t)=R_{r}+r_{D S 0}+r_{D S}\left(U_{G S}(t)\right)
$$

where

$$
U_{G S}(t)=A_{s} \sin (2 \pi f t),
$$

and $r_{D S 0}$ is a drain-source resistance for $U_{G S}(t)=E_{Z}$.

For the system shown in fig. 10, simulations of the voltage waveform of the capacitor and the discharge current for different values of resistance change frequencies of the capacitor-discharging resistor were performed. The results are presented in fig. 11.

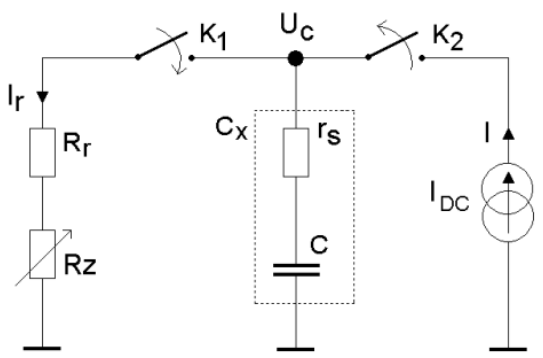

Fig. 9. Circuit for discharging the supercapacitor $C_{x}$ via variable resistance resistor 


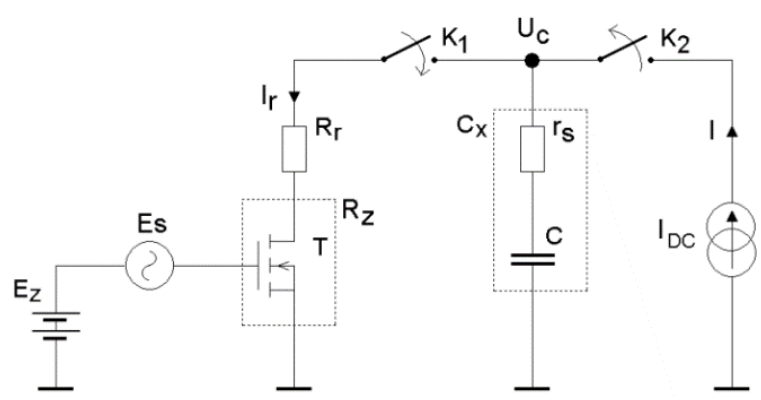

Fig. 10. Circuit for discharging the supercapacitor $C_{x}$ through resistance $r_{D S}$ of a MOSFET transistor

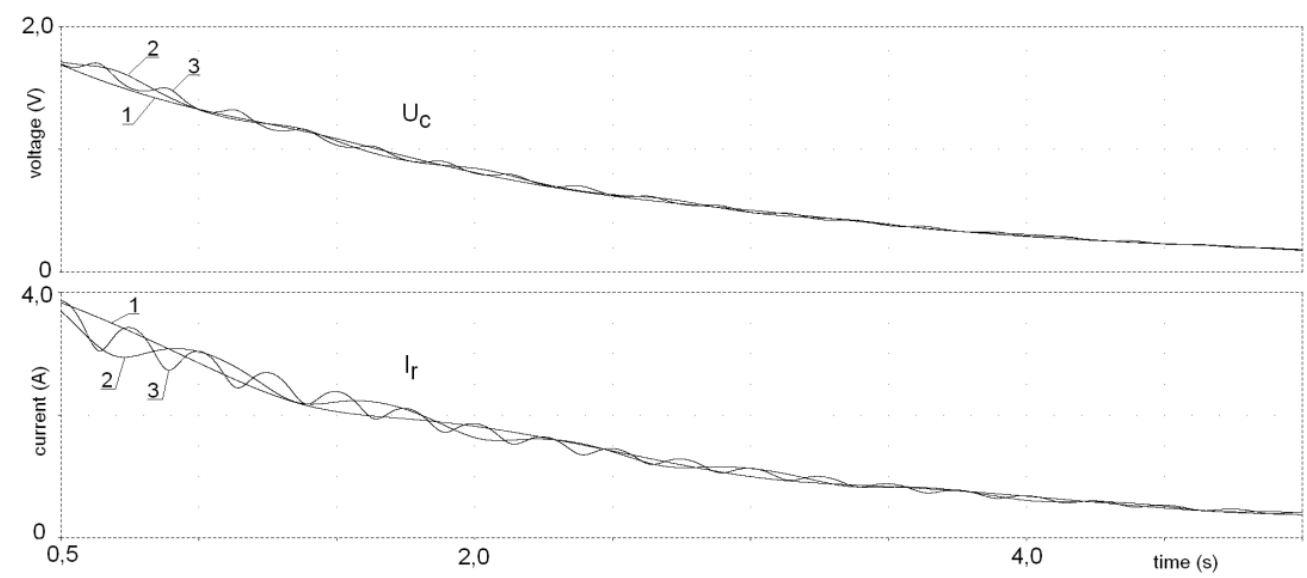

Fig. 11. Supercapacitor voltage $U_{c}$ and current $I_{r}$ for the circuit as shown in fig. 10 for: $R_{r}=0.5 \Omega, C=3 \mathrm{~F}, E_{z}=5 \mathrm{~V}, A_{s}=0.5 \mathrm{~V}$, and for: $1-f=0.6 \mathrm{~Hz}, 2-f=1.5 \mathrm{~Hz}, 3-f=5 \mathrm{~Hz}$

\section{EXPERIMENTAL TESTS RESULTS}

In the experimental part, measurements of the RMS value of the supercapacitor discharge current as a function of the oscillation frequency of the discharge resistance changes were performed. Measurements were performed for several supercapacitors with capacities $0.22 \mathrm{~F}$ to $4.7 \mathrm{~F}$. Below shows the waveform obtained for a supercapacitor of nominal capacity $C_{n}=0.47 \mathrm{~F}$ and nominal voltage $5.0 \mathrm{~V}$. All measurements were performed in the circuit as shown in fig. 6 . The research was conducted in the frequency range from $0.01 \mathrm{~Hz}$ to $10 \mathrm{~Hz}$.

In fig. 12 and 13, the voltage and current changes over time are presented. In the first time range (approx. 60 seconds) the supercapacitor is charged with constant current $\left(i_{C}(t)=50 \mathrm{~mA}\right)$ up to the nominal voltage $5.0 \mathrm{~V}$. After this period, 
the power supply is disconnected. The voltage at the supercapacitor terminals decreases due to the voltage drop at the internal series resistance $\left(i_{C}(t)=0\right)$ and charge redistribution inside the supercapacitor plates. In 150th second, the process of discharging the supercapacitor begins by cyclic changes in the resistance of $R_{z}$ of transistor $T$ according to equation (4). The supercapacitor is discharged by the resistance specified by the sum of the resistances $R_{r}, R_{z}$ and $r_{S}$. Examples of current changes during the charging and discharging cycle are shown in fig. 13 . The tests carried out in this way were repeated for different frequencies of changes in resistance values $R_{Z}$.

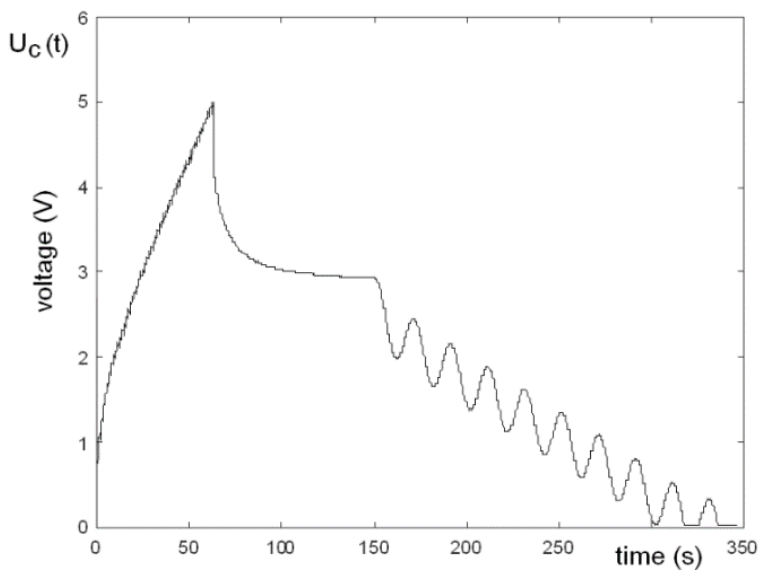

Fig. 12. Measured voltage $U_{c}$ on the capacitor terminals in the circuit as shown in fig. 6, $C_{n}=0.47 \mathrm{~F}, f=0.05 \mathrm{~Hz}, R_{r}=0.5 \Omega$

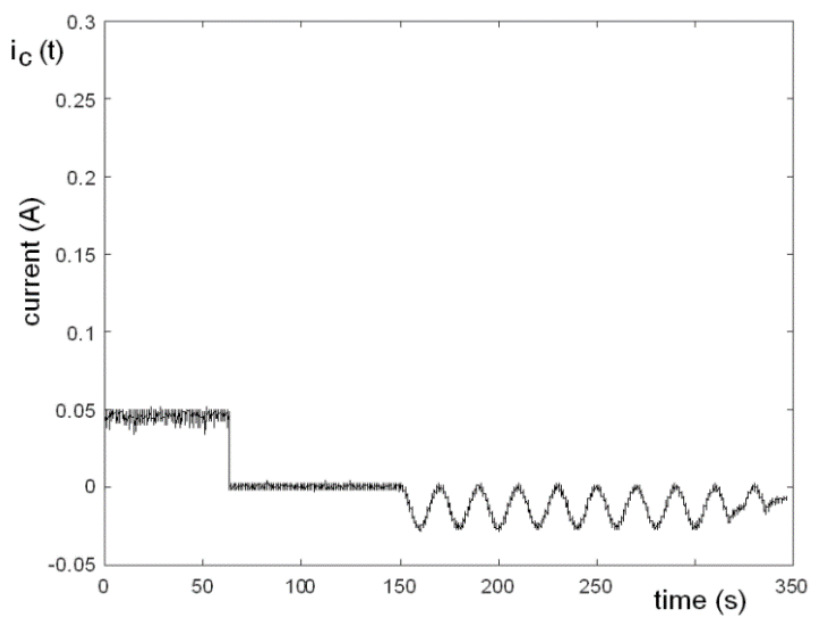

Fig. 13. Measured current $I_{c}$ charging and discharging supercapacitor according to the diagram shown in fig. 6 for $C_{n}=0.47 \mathrm{~F}, f=0.05 \mathrm{~Hz}, R_{r}=0.5 \Omega$ 
In fig. 14 the rms value of discharge current for different frequencies are presented. As in the case of the simulations shown in fig. 2 and 3, the resonance frequency cannot be determined accurately. In the case of supercapacitors, this is mainly due to the very low $Q$ factor of the circuit defined by the equation (1). Supercapacitors are characterized by a relatively high series resistance in relation to a very low inner inductance. Similar results were obtained for other supercapacitors.

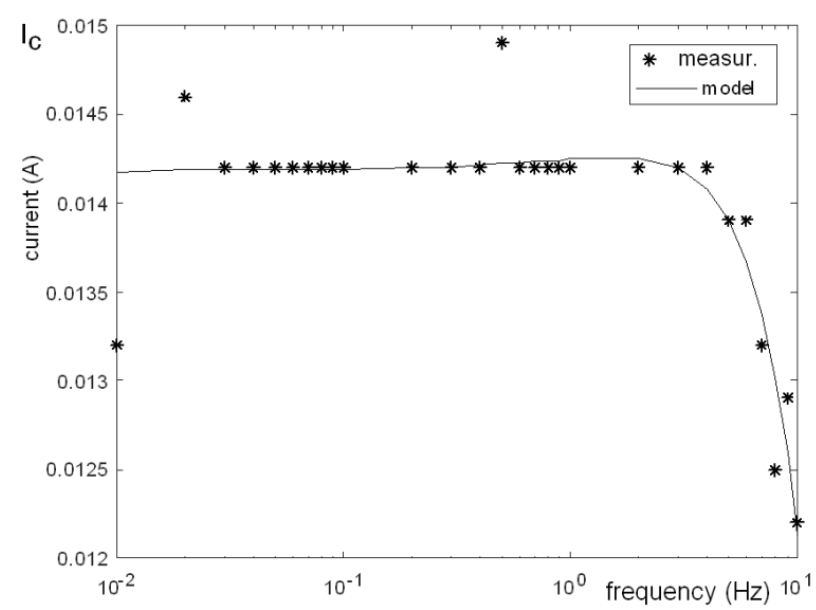

Fig. 14. The RMS value of current $I_{C}$ vs. the frequency $f$ for capacitor $C_{n}=0.47 \mathrm{~F}$ in the frequency range from $0.01 \mathrm{~Hz}$ to $10 \mathrm{~Hz}$

\section{CONCLUSIONS}

The paper presents the results of tests on the performance of supercapacitors subjected to the procedure of discharge by periodically changing loads. Particular attention has been paid to the possibility of the occurrence of resonance phenomenon due to the presence of reactance components $L C$. Unlike the studies of many authors, the resonance phenomenon was attempted to be obtained during the supercapacitor discharge cycle through periodically changing resistance. This approach enables laboratory enforcement of potential situations in supercapacitor operation system.

However, the conducted research did not confirm the occurrence of resonance phenomena. Over the entire frequency range, the RMS value of the discharge current was practically constant. The reason may be the very low $Q$ factor of the supercapacitors, which prevents a sudden drop across of impedance. 


\section{REFERENCES}

[1] Conway B. E., Birss V., Wojtowicz J., The role and utilization of pseudocapacitance for energy storage by supercapacitors, 'Journal of Power Source', 1997, Vol. 66, pp. 1-14.

[2] Dzieliński A., Sarwas G., Sierociuk D., Comparison and validation of integer and fractional order ultracapacitor models, 'Advances in Difference Equations', 2011, 2011:11, pp. 1-15.

[3] Frąckowiak E., Béguin F., Carbon materials for the electrochemical storage of energy in capacitors, 'Carbon', 2001, 39, pp. 937-950.

[4] Freeborn T. J., Maundy B., Elwakil A. S., Measurement of Supercapacitor Fractional-Order Model Parameters From Voltage-Excited Step Response, 'IEEE Journal on Emerging and Selected Topics in Circuits and Systems', 2013, Vol. 3, No. 3, pp. 367-376.

[5] Jakubowska-Ciszek A., Walczak J., Analysis of the transient state in a parallel circuit of the class $R L_{-} \beta C_{-} \alpha$, 'Applied Mathematics and Computation', 2018, Vol. 319, pp. 287-300.

[6] Kaczorek T., Rogowski K., Fractional linear systems and electrical circuits, 'Studies in Systems, Decision and Control', 13, Springer, 2015.

[7] Martin R., Quintana J. J., Ramos A., de la Nuez I., Modeling Electrochemical Double Layer Capacitor, from Classical to Fractional Impedance, The 14th Medditeranean Electrotechnical Conf., Ajaccio, 4-7 May 2008, pp. 61-66.

[8] Radwan A. G., Resonance and Quality Factor of the RL_ $\beta C_{-} \alpha$ Fractional Circuit, 'IEEE Journal on Emerging and Selected Topics in Circuits and Systems', 2013, Vol. 3, No. 3, pp. 377-385.

[9] Radwan A. G., Salama K. N., Passive and Active Elements Using Fractional $L_{-} \beta C_{-} \alpha$ Circuit, 'IEEE Transactions on Circuits and Systems I: Regular Papers', 2011, Vol. 58, No. 10, pp. 2388-2397.

[10] Sierociuk D., Sarwas G., Twardy M., Resonance phenomena in circuits with ultracapacitors, 12th International Conference on Environment and Electrical Engineering, Wroclaw 2013, pp. 197-202.

[11] Walczak J., Jakubowska A., Resonance in series fractional order $R L_{-} \beta C_{-} \alpha$ circuit, 'Przegląd Elektrotechniczny', 2014, No. 4, pp. 210-213.

[12] Walczak J., Jakubowska A., Analysis of parallel resonance RLC $\alpha$ circuit with supercapacitor, 'Computer Applications in Electrical Engineering', 2014, Vol. 12, pp. 1-8.

[13] Westerlund S., Ekstam L., Capacitor Theory, 'IEEE Transaction on Dielectrics and Electrical Insulation', 1994, Vol. 1, Issue 5, pp. 826-839.

\section{WŁASNOŚCI SUPERKONDENSATORÓW PRZY ZMIENNYM OBCIĄŻENIU}

\section{STRESZCZENIE}

W artykule przedstawiono wyniki analiz zjawiska rezonansu szeregowego w układzie zawierającym superkondensatory. Specyficzne cechy takich elementów, szczególnie zjawiska dyfuzji, powodują, że ich własności dynamiczne znacznie różnią się od właściwości typowych kondensatorów. 
Prezentowane wyniki badań, w odróżnieniu od większości prac innych autorów, uzyskano podczas rozładowywania superkondensatorów poprzez okresowo zmieniającą się rezystancję. Takie postępowanie odpowiada rzeczywistym warunkom, w jakich superkondensatory mogą być rozładowywane przez zmieniające się okresowo obciążenie. Analiza warunków rezonansowych jest bardzo ważna, szczególnie w układach zasilania, gdzie superkondensatory często pełnią rolę elementów magazynujących energię. Przeprowadzone badania symulacyjne dla wybranych superkondensatorów i częstotliwości zmian obciążenia zweryfikowano w sposób praktyczny na specjalnie przygotowanym układzie testowym.

Słowa kluczowe:

rezonans elektryczny, superkondensator, zmienne obciążenie.

Article history

Received: $\quad 06.09 .2019$

Reviewed: 20.09.2019

Revised: $\quad 27.09 .2019$

Accepted: $\quad 30.09 .2019$ 